\title{
Photoperiodic Control of the Germination of Eragrostis Seeds
}

\author{
by Sigeo IsikawA*, Tadashi FujI* and Yasutsugu YоконамA*
}

Received July 11, 1960

In studies on seed germination under various conditions, it was found that seeds of several species germinated better under long daily light periods than under short ones ${ }^{1,2,3}$, ).

The photoperiodic control of seed germination has been reported in a number of photoblastic seeds by Isikawa ${ }^{4}$ ). Black and Wareing ${ }^{5}$ ) demonstrated the requirement of long photoperiods for high germination of Betula pubescens Ehr. seeds and its dependence on temperature. In addition they showed that the length of the daily dark period played a more determinative rôle than did the length of the light period in this photoperiodic response, as in the flowering responses in plants.

Isikawa indicated that many of the "Light-favored Seeds" were "Short Day Seeds" the germination of which was promoted in the presence of the dark period like the flowering of short-day plants $\left.{ }^{4}\right)$. Black ${ }^{6}$ ) and Black and Wareing ${ }^{7}$ ) have investigated the responses in such a "short-day" seeds, and demonstrated that the response is markedly photoperiodic, a high germination percentage being obtained under short days. A few further theoretical reports, however, have been written concerning the requirement of promotive dark periods for germination. The present studies were undertaken to investigate the requirement for seed germination of the dark period corresponding to that in flowering of short-day plants.

\section{Material and Methods}

The work performed with Eragrostis ferruginea Beauv. which had been collected in Tokyo, October 6, 1959.

As experimental germinating bed, $6.5 \mathrm{~cm}$. diameter Petri dish with about $10 \mathrm{~m} l$. of $0.7-0.8 \%$ agar solution was used. On the solidified surface, a small amount of water was added, and 100 seeds were disseminated into each Petri dish. Each dish was wrapped in thick black paper immediately, and placed in an incubator, which was usually controlled within $\pm 1^{\circ}$. In all experiments, the seeds were maintained in darkness throughout, except during the periods of irradiation.

Main light periods were generally supplied as cool white fluorescent light of about 1500 lux. The red or blue radiation was given from cool white fluorescent lamps, through a filter of two layers of red or blue cellophane, respectively, and incandescent light filtered through water and red and blue cellophane was the source of far-red radiation.

Temperature was always controlled at $30^{\circ}$. Two lots of 100 seeds were used for each treatment and the same experiment was repeated several times so as to make sure of the results.

\section{Results}

Preliminary experiments concerning the effects of light on germination indicated

* Botanical Institute, Faculty of Science, Tokyo University of Education, Otsuka, Tokyo, Japan. 
that seeds of Eragrostis ferruginea Beauv. exhibited low germination in continuous exposure to light, although light was obligatory for their germination. But, germination was high even under a long light period if the seeds were given favorable lengths of dark period immediately after soaking (Table 1).

Table 1. Effects on germination of various lengths of darkness immediately after soaking. Light was given for 72 hrs. after dark period, till germination percentages were counted.

\begin{tabular}{c|rrrrrrrr}
\hline $\begin{array}{c}\text { Lengths of darkness } \\
(\mathrm{hr} .)\end{array}$ & 0 & 6 & 12 & 18 & 24 & 36 & 48 & 72 \\
\hline $\begin{array}{c}\text { Germ. } \\
(\%)\end{array}$ & 24 & 27 & 49 & 60 & 72 & 70.5 & 55.5 & 12.0 \\
\hline
\end{tabular}

This experiment indicated that the length of the dark period was probably the critical factor for germination, as it was in most photoperiodic phenomena.

To observe the optimum length of this dark period, the seeds which had been soaked in water for various durations at $30^{\circ}$ in the dark were exposed to light for various lengths (Fig. 1). The effect of irradiation increased rapidly during the first $24 \mathrm{hrs}$. after the beginning of imbibition. And then the germination percentages decreased gradually with further increase of the dark imbibition time. These experimental results showed that the dark period of $24 \mathrm{hrs}$. was necessary to obtain the highest germination and its effect might be compared with that of the dark period on the flowering of short-day plants.

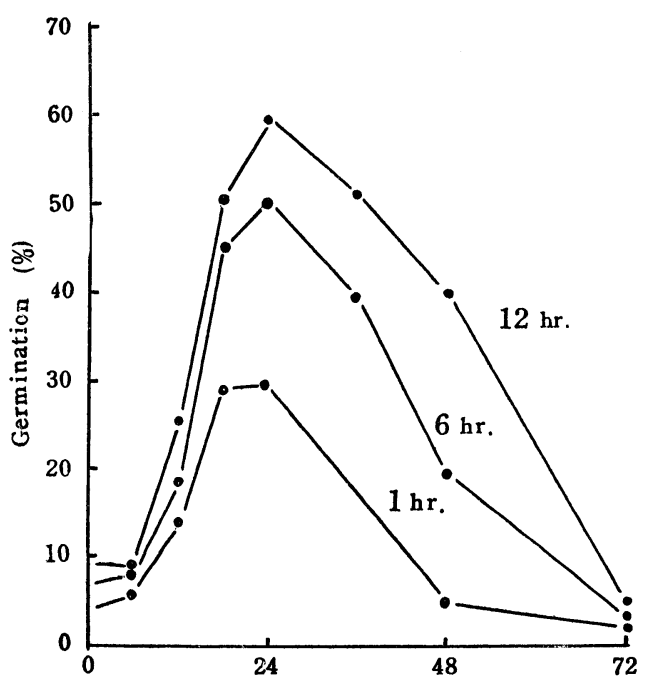

Time in Hrs, of Imbibition before Irradiation

Fig. 1. Light-sensitivity of seed, exposed for 1,6 and $12 \mathrm{hrs}$. to 1500 lux.

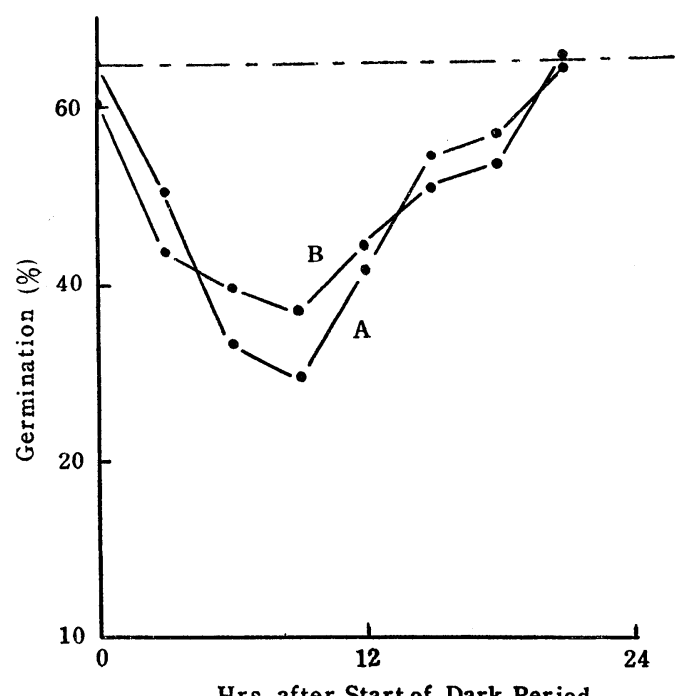

Hrs. after Start of Dark Period

Fig. 2. Effect on germination of a lightinterruption of red for $1 / 6$, or blue for $1 / 6$ $\mathrm{hr}$. given at various times in the $24 \mathrm{hr}$. dark period.

A: Red light B: Blue light

Flowering of short-day plants can be inhibited even under the favorable photoperiods, if the long dark period is interrupted with light. Germination of Eragrostis seeds was also inhibited when a brief light interruption was applied during the dark 
period (Figs. 2 and 3). Namely, red for $1 / 6$, blue for $1 / 6$ or far-red for $1 \mathrm{hr}$. was given at various times in the dark period, and the subsequent light period of $12 \mathrm{hrs}$. was given after the $24 \mathrm{hr}$. dark period. As shown in Fig. 2, the light-break with red or blue light was most effective when given at about the 9 th $\mathrm{hr}$. after the start of the dark period. It was observed, however, that the interruption with far-red light became more effective in the latter half of the dark period (Fig. 3).

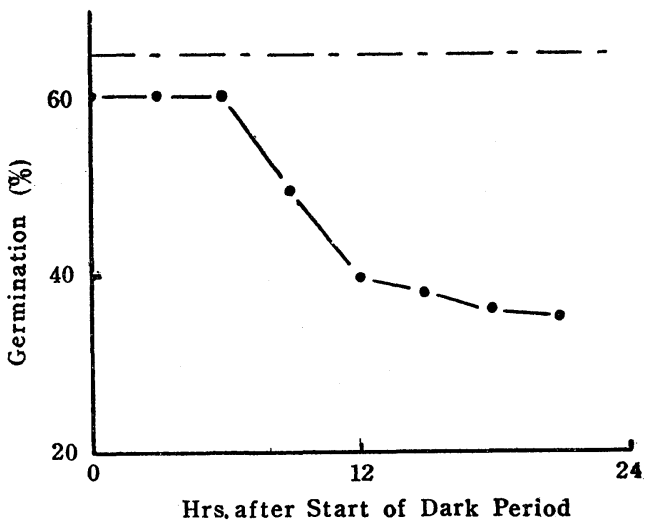

Fig. 3. Effect on germination of a lightinterruption of far-red for $1 \mathrm{hr}$. given at various times in the $24 \mathrm{hr}$. dark period.

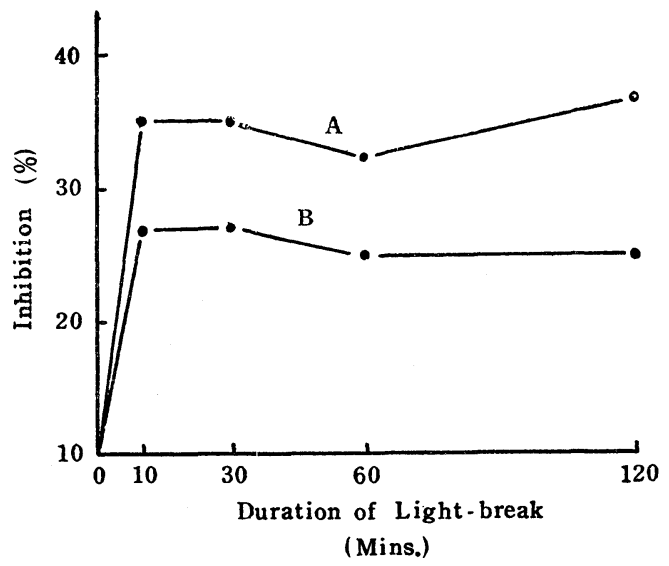

Fig. 4. Effect on germination of various lengths of light interruptions given at $8 \mathrm{hrs}$. after the beginning of dark period.

A: Red light B: Blue light

Table 2. Effect of alternate exposures to red and far-red or to blue and far-red irradiations given at the 8 th $\mathrm{hr}$. after the dark period started.

\begin{tabular}{l|c|c|c}
\hline \multicolumn{1}{c|}{ Treatment } & Germ. \% & Treatment & Germ. \% \\
\hline R & 30.0 & B & 42.0 \\
R-FR & 57.0 & B-FR- & 50.5 \\
R-FR-R & 32.0 & B-FR-B & 40.5 \\
R-FR-R-FR & 56.0 & B-FR-B-FR & 52.0 \\
-FR- & 55.5 & & \\
\hline
\end{tabular}

In the next experiment, the dark period was interrupted with various lengths of irradiation when $8 \mathrm{hrs}$. elapsed from its start. The results are shown in Fig. 4. A light-break of only 10 minutes was effective in inhibiting the germination. However, these inhibitions were reversed by far-red irradiation given immediately after the red or blue light and the germination was controlled by the light last received (Table 2). In this experiment, red, blue and far-red lights were given for $1 / 6 \mathrm{hr}$., respectively.

On the other hand, the inhibitive effect of far-red irradiation in the latter half of the 24-hr. dark period was not reversed by red or blue light.

The present results clearly indicated that the germination of Eragrostis seeds was affected in a similar way to the flowering of short-day plants by the light-break given during the dark period.

\section{Discussion}

Many works have been reported concerning the light action on seed germination. 
Various aspects of these problems were summarized in the recent review by Evenari $\left.{ }^{8}\right)$. A few workers, however, have discussed the requirement of dark period in the germination of seeds.

The seeds of Eragrostis ferruginea Beauv. germinated in the presence of dark period immediately after soaking and subsequent light period. These results indicated that light was obligatory for the germination of Eragrostis seeds. The germination of Nemophila insignis seeds is promoted by short days and strongly inhibited under long days ${ }^{7}$ ). The response of Eragrostis seeds is also affected by the duration of both the light and the dark periods, but particularly by the latter, as postulated by Black and Wareing ${ }^{5}$ ) and Vaartaja ${ }^{9}$.

Eragrostis seeds, once given an inductive photoperiodic treatment, may be induced to germinate. The optimum dark period was $24 \mathrm{hrs}$. and its effect corresponded to that on flowering of short-day plants.

In the preliminary high-intensity-light period in photoperiodic response, it has been believed on the basis of the work of Liverman and Bonner ${ }^{10}$ ) and others, that photosynthesis provides substrates necessary for the consummation of the subsequent dark steps. It is noteworthy, however, that the dark process commence without preliminary light process in the germination of Eragrostis seeds.

The dark process is different from the dark imbibition prior to irradiation in the light-sensitive seed, because the germination is inhibited if the inductive dark period is blocked with a short irradiation of red or blue light. Earlier workers reported that the seed of Phacelia tanacetifolia is inhibited by both blue and red lights ${ }^{11,12}$ ). And it was found that Nemophila seed is inhibited by blue light, but only slightly inhibited under the filters peaking at 542, 547, 596 and $651 \mathrm{~m} \mu$. In Eragrostis seeds the lightbreak is most effective when given at about the 9 th $\mathrm{hr}$. after the dark period started.

It has been observed that germination of Lactuca sativa var. Grand Rapids seeds was either promoted or inhibited in the blue region after the pigment system had been displaced to an extreme of potential inhibition or promotion of germination, respective$\left.1 y^{13}\right)$. It is noteworthy, however, that the light interruption with blue light is effective at the same part of the dark process as the red interruption is effective, although the effect is less in the former.

The dark process is also blocked with a short irradiation with far-red energy, but its inhibitive effect appears in the latter half of the dark period.

Responses of plant materials to irradiation indicate that germination and many other aspects of development are controlled by a reversible photoreaction $\left.{ }^{14,15,16}\right)$, involving two forms of a pigment, with action maxima near $6600 \AA$ and $7350 \AA$. In Eragrostis seed, this photoreversible action is also observed in the first half of the dark period. But in the latter half, the inhibitive effect with far-red is not reversed by red or blue light.

Moreover, Borthwick et al. were able to obtain only slight reversal of the promotive effect of red when the latter was followed by blue $\left.{ }^{13}\right)$. In order to explain the promotive and inhibitory effects of blue light, Borthwick et al. ${ }^{13}$ ) have postulated that the photoreceptors for the red and far-red responses must have absorptive regions in the blue which overlap. It is highly interesting that the germination of Eragrostis seeds is photoreversibly controlled by blue and far-red energies. These have suggested that new insights into the process of germination would be forthcoming from such studies.

\section{Summary}

1. Light is obligatory for the germination of Eragrostis seeds but the dark period 
corresponding to that in flowering of short-day plants is required immediately after soaking. And the high-intensity-light process prior to the dark process is not observed. Germination is maximal under the dark period of $24 \mathrm{hrs}$. followed by light and decreases under continuous light irradiation.

2. The germination-promoting effects of the long dark period are inhibited by brief interruptions with red, blue or far-red energy, such interruptions being most effective for red and blue at the 9 th $\mathrm{hr}$. after the start of the dark period, and for far-red energy in the latter half of the dark period.

3. Repeated alternations of red and far-red radiant energies repeatedly result in red inhibition and far-red repromotion of germination in the first half of the dark period, but not in the latter half.

4. Another important feature is the photocontrol of germination by a succession of alternate blue and far-red irradiations in the first half of the dark period. The germination is regulated by the light last received, being inhibited with blue energy and repromoted with far-red.

\section{References}

1) Isikawa, S., and Shimogawara, G., J. Japan Forestry Soc. 36: 318 (1954). 2) Nagao, M., Esashi, Y., Tanaka, T., Kumagai, T., and Fukumoto, S., Plant and Cell Physiol. 1: 39 (1959). 3) Vaartaja, O., Phytopathology 42: 501 (1952). 4) Isikawa, S., Bot. Mag. Tokyo, 67: 51 (1954) 5) Black, M., and Wareing, P. F., Physiol. Plantarum 8: 300 (1955). 6) Black, M., Ph. D. thesis. University of Manchester, England. (1957). 7) Black, M., and Wareing. P. F., Nature 180: 395 (1957). $\quad$ 8) Evenari, M., Radiation Biology 111: 519 (1956). 9) Vaartaja, O., Canada. Jour. Bot. 34: 377 (1956). $\quad$ 10) Liverman, J., and Bonner, J., Botan. Gaz. 115: 121 (1953). 11) Meischke, D., Jahr. Wiss. Botan., 83: 395 (1936). 12) Resühr, B., Planta 30: 471 (1939). 13) Borthwick, H. A., Hendricks, S. B., Parker, M. W., Toole, E. H., and Toole, V. K., Bot. Gaz. 115: 205 (1954). 14) Borthwick, H. A., Hendricks, S. B., Parker, M. W., Toole, E. H., and Toole, V. K., Proc. Nat. Acad. Sci. 38: 662 (1952). 15) Borthwick, H. A., Hendricks, S. B., and Parker, M. W., Proc. Nat. Acad. Sci. 33: 929 (1952). 16) Isikawa, S., and Fujii, T., Plant and Cell Physiol. (in the press).

\section{摘要 \\ 石川茂雄・藤伊正・横浜康継： カゼクサ種子の発芽に括ける光週期的処理}

1）種子の発芽に特いて，発芽過程を促進する暗期の積極的効果は，いまだ見出されていないが，カゼク サの種子の発芽は短日植物に郝ける花芽形成々同様に暗期が存在することによって促進される。しかもこ の暗期は播種と同時に始まる。したがって，短日植物に特けるような high-intensity-light process は観 察されなかった。

2) この暗期の発芽促進効果は，red，blue，拈よび far-red の各波長の光の短時間照射によって抑制さ れ，乙かも red と blue の光はともに暗期の 9 時間目のところでもっとも強い抑制を示す。一方 far-red の抑制効果は, 暗期の後半に招いて初めて現われてくる.

3）暗期の前半に呿ける red と blue の抑制効果は far-red の光によってとりのぞかれ，この抑制と促 進とは何回もくりか它すことができる。 しかし暗期の後半に特ける far-red の抑制効果は，red または blue によってとりのぞかれることはなかった。（東京教育大学理学部植物学教室） 